\title{
Successful Separation of Conjoined Twins: Experience of a Tertiary Care Hospital
}

\author{
SHAHNOOR ISLAM ${ }^{1}$,SADRUDDIN AL MASUD ${ }^{2}$, NAZMUL HAIDER CHAWDHARY ${ }^{3}$, M MOZAFFAR \\ HOSSAIN $^{4}$, SM SHAFIQUL ALAM ${ }^{5}$, M ABUL KALAM ${ }^{6}$, ASIT CHANDRA SARKAR ${ }^{7}$, M RAZIUL HUQ $^{8}$, \\ M SHAMSUZZAMAN ${ }^{9}$, AKM AMIRUL MORSHED $^{10}$, SHARMIN AKHTAR RUPA $^{11}$
}

\begin{abstract}
Background: The separation of conjoined twins presents a unique challenge to many pediatric surgical specialties. Meticulous preoperative investigations, planning and multidisciplinary team approach led by pediatric surgeon contribute to the success of surgical separation. The aim of this study is to share our experiences of one hospital to enhance skill for treating conjoined twins regarding anatomic variations, investigations, surgical aspects, outcomes and rehabilitation.

Methodology: All cases of symmetrical conjoined twins who were treated from July 2009 to February 2018 at the Pediatric Surgery Department of Dhaka Medical College Hospital, Dhaka, Bangladesh were included in this prospective type of study. All types of parasitic twins were excluded. Prenatal ultrasound diagnosis, gender, birth weight, anatomy of the twins, the age and weight at the time of the separation surgery, the length of surgery, the duration of anesthesia during the separation surgery, a detailed description of the separation surgery, the type of skin closure, postoperative complications and death were studied.

Results: There were three sets of thoraco-omphalo-ischiopagus twins, one set of thoraco-omphalopagus twins, one set of pygopagus twins. Three sets had no prenatal visit or ultrasound evaluation. Two sets of conjoined twins were failed to separate due to the complexity of the organs that were shared by both twins and instability leading to death. Only one set of pygopagus twins was successfully separated. Emergency colostomies were done on pygopagus twins due to the presence of anorectal anomalies. The surgical survival rate was $100 \%$. One set of twins who did not undergo separation due to refusal of treatment was currently alive. One set of twins was under evaluation and currently alive.
\end{abstract}

Conclusion: The overall success of conjoined twin separation depends on the experience and preparedness of treating team led by pediatric surgeon and resources available at the hospital. No single discipline can expect to have all the necessary talents.

Keywords: Conjoined Twins, Surgical Separation, Pygopagus, Omphalopagus, Thoraco-omphalo-ischiopagus.

1. Professor, Department of Pediatric Surgery, DMC, Dhaka

2. Assistant Professor, Department of Pediatric Surgery, DMC, Dhaka

3. Assistant Registrar, Department of Pediatric Surgery, DMCH, Dhaka

4. Professor \& Head, Department of Anaesthesiology, DMC, Dhaka

5. Senior Consultant, Department of Anaesthesiology, DMCH, Dhaka

6. Professor, Department of Burn \& Plastic Surgery, DMC, Dhaka

7. Professor \& Head, Department of Neurosurgery, DMC, Dhaka

8. Professor, Department of Neurosurgery, DMC, Dhaka

9. Professor \& Head, Dept. of Orthopaedic Surgery, DMC, Dhaka

10. Professor \& Head, Department of Pediatric Hematology and Oncology, DMC, Dhaka

11. Associate Professor, Department of Radiology \& Imaging, Popular Medical College, Dhaka,

Correspondence: Prof. Dr. Shahnoor Islam, Department of Pediatric Surgery, Dhaka Medical College Hospital, Dhaka-1000, Bangladesh. Mobile: +88-01714497128, E-mail: shahnoor6989@ yahoo.com copywright@2017tofatohurashahnoor

Received: 14 May 2018

Accepted: 21 June 2018

\section{Introduction}

Conjoined twins have fascinated mankind throughout the centuries because of the rarity of this type of birth; however, conjoined twins have always been a challenge for physicians. Eng and Chang Bunker are likely the most famous pair of conjoined twins. These twins were born in Siam in 1811, taken to the United States by a circus company and exhibited as the curious "Siamese Twins", thus providing the origin of the colloquial term. ${ }^{1}$ The brothers lived for 63 years without considering separation, and they married sisters and fathered 21 children.

As a rare outcome of a monoamniotic and monochorionic gestation, conjoined twins occur when 
two identical individuals are joined by part of their anatomy and share one or more organs. The incidence of conjoined twins ranges from 1:50,000 to $1: 100,000$ live births. This number could be higher, but most of these pregnancies result in miscarriages and still births; only $18 \%$ of all conjoined infants survive $^{2}$ and approximately $35 \%$ of live births die within the first 24 hours, and only $18 \%$ of all conjoined twins survive longer than 24 hours.

Conjoined twins are classified based on the terminology proposed by Spencer and colleagues. ${ }^{3}$ Based on this terminology, we use the most prominent site of union plus the suffix "pagus," which is a Greek word meaning "that which is fixed." Spencer et al. also divided the twins into three major groups: twins with a ventral union, twins with a dorsal union and twins with a lateral union. The first major group includes four types: cephalopagus (head), thoracopagus (chest), omphalopagus (umbilicus) and ischiopagus (hip). The dorsal union includes three types: pygopagus (sacrum), rachipagus (spine) and craniopagus (cranium). The last major group includes just one type of twins that is referred to as parapagus (side) twins.

The surgical separation of conjoined twins is now the principal aim of all medical teams who treat this uncommon condition. However, separation presents both surgical and anesthetic challenges. In addition, this surgery is sometimes not possible because the anomalies are rare and difficult to manage, even for experienced surgeons. ${ }^{4}$ In Brazil, when a diagnosis of conjoined twinning is made; the pregnant mother is usually referred to a tertiary hospital that specializes in obstetric and perinatal care. Although there are several reports in the medical literature about conjoined twinning, only one Brazilian study has been published on this issue; that study was performed in a tertiary perinatology referral university center over a period of 25 years. The authors reported the occurrence of 14 pairs of conjoined twins and the successful separation of only one pair of omphalopagus twins. ${ }^{5}$ If we share our experiences and learn from others, we can enhance our knowledge and skills for treating conjoined twins focusing on surgical aspects, anatomic investigations and outcomes.

\section{Patients and Methods}

This prospective type of study includes all cases of symmetrical conjoined twins treated between July
2009 to February 2018 at the Department of Pediatric Surgery, Dhaka Medical College Hospital, Dhaka1000, Bangladesh. Cases of parasitic conjoined twins considered by some authors to be "incomplete conjoined twins," were also excluded from this study. The study was approved by the ethical committee of the institution, and we obtained parental approval to publish the children's pictures. Patient information was obtained by a structured questionnaire.

Initial postnatal evaluation was directed at the history, physical examination with routine roentgenograms and condition of the infants. Perinatal data included prenatal ultrasound diagnosis, gender, birth weight and the anatomy of the twins. The patients were classified based on the most prominent site of fusion, based on the embryological classification proposed by Spencer. ${ }^{3}$ After a careful imaging evaluation, the possibility of separation surgery was determined, and the twins were divided into two groups as follows:

1. Conjoined twins who were not candidates for surgical separation

2. Conjoined twins who underwent surgical separation. In this group, the following data were collected and analyzed: the age and weight at the time of the separation surgery, the length of surgery, the duration of anesthesia during the separation surgery, a detailed description of the separation surgery, the type of skin closure, postoperative complications and death.

A multispecialty team (include neonatologists, pediatricians, cardiologists, pediatric surgeons, orthopedic surgeons, neurosurgeons, urologists, gynecologists, thoracic surgeons, anesthesiologists, radiographer, Operating room nurses, technicians, security personnel, photographer and video personnel ) led by pediatric surgeon was constituted and a detailed strategy was framed. Examinations of the twins for additional congenital anomalies were also important. Measurement of the estimated shared surface area was done in determining whether adequate skin and soft tissue were present for closure. 3-D Magnetic Resonance Imaging, Computerized Tomography scan was done for surgical decision making. Degree of shared circulation was estimated from the preoperative diagnostic studies. Two separate teams from each specialty were constituted. All of the equipment was labeled and color coded for each infant. To achieve perfection, multiple rehearsals were carried. Detailed 
counseling of parents was done about the likelihood of successful separation, post-operative care, outcomes and rehabilitation. Plans were made for per operative and periodic press conferences. Plans were also made for recording the events involving a still photographer and video recording.

\section{Results}

Five sets of conjoined twins were analyzed. There were one set of pygopagus twins (Fig.1), one set of thoraco-omphalopagus twins (Fig.2), three sets of thoraco-omphalo-ischiopagus twins (Fig.3, 4, 5). Most of the pairs were female, with 3female sets (separate external genitalia) and 2 male sets (common external genitalia). The mean birth weight of the twin pairs was $4 \mathrm{~kg}$. No prenatal diagnosis was made in 5 pregnancies $(100 \%)$. Four births were accomplished by cesarean section and one by normal vaginal delivary at home. The age at separation surgery was 10 months. The weight of the twin sets at the time of the separation surgery was $10 \mathrm{~kg}$. Cardiac defects were present in $100 \%$ of twin pairs and other associated malformations were not

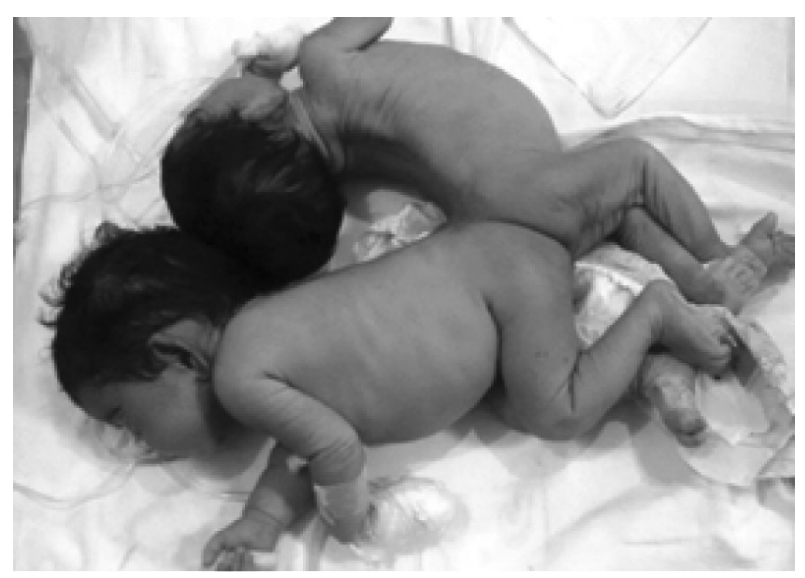

Fig.-1: pygopagus conjoined twins
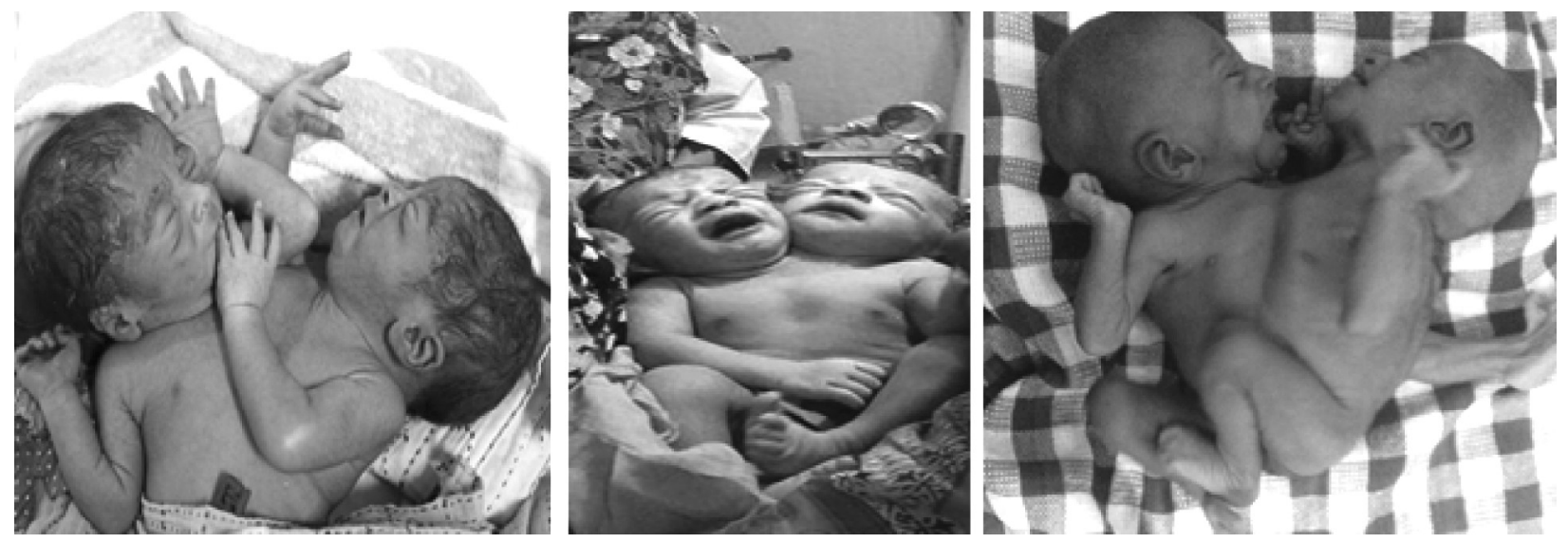

Fig.-3, 4 and 5: Thoraco-omphalo-ischiopagus conjoined twins

possible to assess in three cases. Two sets of conjoined twins were failed to separate due to the complexity of the organs that were shared by both twins and instability leading to death in two sets. Only one set of pygopagus twins were successfully separated, which survives in excellent health conditions till now. Emergency colostomies were done on pygopagus twins due to presence of anorectal anomalies. The surgical survival rate was $100 \%$. One set of twins refused treatment was currently alive. One set of twins was waiting for evaluation and currently alive.

\section{Operative management Pygopagus (Fig.1)}

When separation was pursued after exhaustive imaging examinations, the technical aspects were always discussed with the anesthesiologists, multidisciplinary team members and rehearsed. The twins were comfortably positioned on the surgical table, and the procedure was started. Two teams of anesthesiologists for each twin were required. Before endotracheal intubation, each twin underwent radial

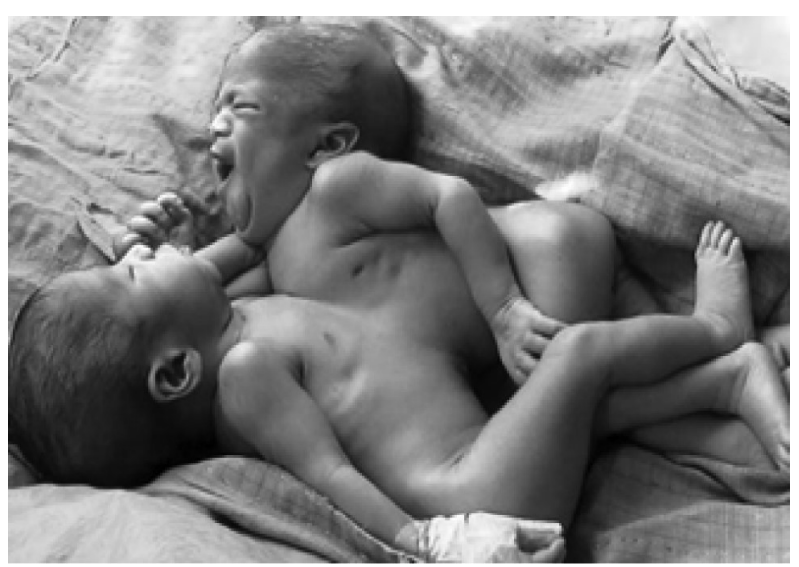

Fig.-2: Thoraco-omphalopagus conjoined twins 
arterial cannulation for complete monitoring during the operation. A Foley bladder catheter was also inserted in each. The separation procedure was always performed by a single surgical team led by pediatric surgeon. After the separation, the second twin was moved with the corresponding anesthesiologists and a second team of surgeons to another surgical room for the final reconstruction procedures. The reconstruction of the first twin was completed by the surgical team that performed the separation. After the separation procedure, all of the infants were transferred to the postoperative care unit for strict monitoring. The infant recovered very well. Now they are waiting for two more surgeries with good health.

\section{Non-operative management}

Two pairs of twins were not candidates for separation based on imaging evaluations. The separation procedure was not possible due to the complexity of organs that were shared by both twins, mainly the liver and heart and died of sepsis. The decision was made after consulting with the parents and the medical board of the Institution.

Thoraco-omphalopagus conjoined twins (Fig. 2)

One set of thoraco-omphalopagus conjoined twins was not separated, this set died during the neonatal period.

\section{Thoraco-omphalo-ischiopagus (Fig.3, 4, 5)}

Two set of complex thoraco-omphalo-ischiopagus twins did not undergo separation. One of these sets of twins died five days after birth due to serious cardiac defects (Fig.3).

The second set of thoraco-omphalo-ischiopagus twins presented with two head, two arms, two legs, common anus and male genitalia. At the time of publication, these twins were still alive (Fig.4).

Another sets of thoraco-omphalo-ischiopagus twins presented with two head, four arms, three legs (one fused limb), and separate perineal region. On echocardiography, two separate cardia were present (Fig.5).

Table-I

Summarizes perinatal data, separation surgery data and outcomes of conjoined twins treated at Department of Pediatric Surgery, Dhaka Medical College Hospital, Dhaka-1000, Bangladesh

\begin{tabular}{|c|c|c|c|c|c|}
\hline Case & $\begin{array}{l}\text { Gender, } \\
\text { Birth } \\
\text { weight }\end{array}$ & $\begin{array}{l}\text { Types of } \\
\text { conjoined } \\
\text { twins }\end{array}$ & $\begin{array}{l}\text { Prenatal } \\
\text { USG, Place and } \\
\text { mode of delvery }\end{array}$ & $\begin{array}{l}\text { Alain orgens } \\
\text { shared }\end{array}$ & Outcomes \\
\hline 01 & $\begin{array}{l}\text { Female, } \\
4.8 \mathrm{~kg}\end{array}$ & Pygopagus & $\begin{array}{l}\text { None, normal vaginal } \\
\text { delivery at home }\end{array}$ & $\begin{array}{l}\text { Sacrum, coccye, } \\
\text { anus, } \\
\text { dural covering. } \\
\text { spinal cord }\end{array}$ & $\begin{array}{l}\text { Emergency colostomy at } 22 \text { days. } \\
\text { successful separation surgery at } \\
10 \text { months with } 10 \mathrm{~kg} \text { weight, } \\
\text { duration of surgery and anesthesia } \\
\text { was } 9 \text { hours, postoperatise cerecrospina: } \\
\text { fuid leakage and wound } \\
\text { infection, now in good heath. } \\
\text { westing for lwo more surgeries for } \\
\text { correction of anorectal malsormation }\end{array}$ \\
\hline 02 & $\begin{array}{l}\text { Female, } \\
4 \mathrm{~kg}\end{array}$ & $\begin{array}{l}\text { Thoraco } \\
\text { omphalopagus }\end{array}$ & $\begin{array}{l}\text { None, ceasarian } \\
\text { section at hospital }\end{array}$ & Hear? and Lver & $\begin{array}{l}\text { Tyins died len days afler birtt } \\
\text { due to sepsis }\end{array}$ \\
\hline 03 & $\begin{array}{l}\text { Male. } \\
4.2 \mathrm{~kg}\end{array}$ & $\begin{array}{l}\text { Thoraco- } \\
\text { omphaio- } \\
\text { ischiopagus }\end{array}$ & $\begin{array}{l}\text { Prenalal } \\
\text { ultrasonogram } \\
\text { without diagnosis } \\
\text { about twinning. } \\
\text { ceasarlan section at } \\
\text { hospial }\end{array}$ & $\begin{array}{l}4 \text { hands, } 2 \text { legs, } \\
\text { comm on anus and } \\
\text { external geñasa }\end{array}$ & $\begin{array}{l}\text { Perinetal asphyola and prog- } \\
\text { ressive bradycarda due to } \\
\text { congenilal carciac defects: set } \\
\text { died with } 5 \text { days of Ife }\end{array}$ \\
\hline 04 & $\begin{array}{l}\text { Male, } \\
4 \mathrm{~kg}\end{array}$ & $\begin{array}{l}\text { Thoraco- } \\
\text { omphalo- } \\
\text { ischiopagus }\end{array}$ & $\begin{array}{l}\text { Prenatal } \\
\text { Usrasonogram wilt } \\
\text { diagnosis abous } \\
\text { Ivinning, ceasarian } \\
\text { section at hospalal }\end{array}$ & $\begin{array}{l}2 \text { hands, } 2 \text { legs, } \\
\text { comm on anus and } \\
\text { external genisala }\end{array}$ & $\begin{array}{l}\text { Parents denied separation } \\
\text { surgery due to hight risks. The } \\
\text { twins are alve till nows. }\end{array}$ \\
\hline 05 & $\begin{array}{l}\text { Female, } \\
3.8 \mathrm{~kg}\end{array}$ & $\begin{array}{l}\text { Thoraco- } \\
\text { omphalo- } \\
\text { ischiopagus }\end{array}$ & $\begin{array}{l}\text { Prenaise } \\
\text { ultrasonographic } \\
\text { diagnosis about } \\
\text { Iwónning, cesse- } \\
\text { rian section as } \\
\text { hosptal }\end{array}$ & $\begin{array}{l}4 \text { hands, } 4 \text { legs } \\
\text { (one fused). } \\
\text { separate anus and } \\
\text { separale external } \\
\text { gentasia }\end{array}$ & $\begin{array}{l}\text { At hospltal, } 28 \text { deys afier bith, } \\
\text { stil under evaluation. }\end{array}$ \\
\hline
\end{tabular}




\section{Discussion}

The problems encountered in our series and the lessons learned from our experience during the treatment of these 5 pair of conjoined twins enrich our knowledge regarding surgery in complex pediatric patients. The first difficulty encountered was the anesthesia required for imaging investigations during the pre-separation phase. These imaging investigations included interventional radiological investigations. These procedures provided invaluable insight into potential or actual problems that may arise during or after the separation, such as the difficulties encountered in the pygopagus twins. Two opposing theories have been suggested to explain the sequence of events of conjoined twins. Those supporting a "fusion" process, postulate that with the exception of the parapagus type, all other types of conjoined twins can be explained by the fusion of two separated embryos. ${ }^{5}$

As with every surgery, surgical separation of conjoined twins carries its own risks, which may be avoided by reducing the surgery and anesthesia times. Therefore, a meticulous investigation of the twins' anatomy is as crucial as the improvement of appropriate surgical techniques by training and experience. However, we also learned that, despite carefully studying the twins' anatomy, unexpected anatomical variations are frequently identified during the surgery; the surgical team must be prepared for this variations. The literature advises the use of a multi-disciplinary approach for surgical separation to improve survival rates. ${ }^{2,6,7}$ Therefore, the separation must be performed by a multidisciplinary team led by pediatric surgeon. In our experience, the inclusions of several specialties (neurosurgery, orthopedic, plastic, urologic, and thoracic and radiologists and others) during the separation procedure were leading to better results.

There are various controversies regarding the ideal age at which the separation procedure should be performed. Spitz et al. ${ }^{8}$ preferred to operate at approximately three months of age, which allows time for detailed investigations to be conducted and enables separation to take place when the body wall can still rapidly expand to close substantial defects. However, a high incidence of postoperative wound infection can occur, and separation is very harmful to the body's functional reserves. Therefore, we preferred to operate at approximately 10 months of age, despite some psychosocial issues that may occur during the waiting period. Consequently, the age of our patients at the time of separation surgery was 10 months.

Skin closure always presents a challenge and should be carefully considered before the separation procedure has begun. Many surgeons tend to use tissue expanders ${ }^{1,9-11}$ and sometimes mesh. ${ }^{8,11}$ In a recent review of 12 separated sets of conjoined twins, the author concluded that tissue expanders are not required in most patients. ${ }^{12}$ In our case, we did not use tissue expanders and mesh. We performed skin closure smoothly.

The surgical mortality rate of our series was $0 \%$. Spitz in the United Kingdom reported a mortality rate of $50 \%$ in 12 separation procedures, seven of which were performed emergently. ${ }^{6}$ In a recent publication from the Philippines, the mortality rate of nine sets of twins was $17.7 \% .^{10}$ Based on several publications and the present experience, emergency separations always have dismal outcomes. Therefore, careful deliberation and complete evaluation of the twins before any surgical intervention are important to ensuring that the surgery proceeds smoothly and with good results.

The Pediatric Surgery Department of Dhaka Medical College Hospital, Dhaka-1000, Bangladesh has treated 5 sets of conjoined twins over 8 years, with surgical experience in 1 pair of twins. Considering the surgical outcomes, it is concluded that a wellprepared multidisciplinary team led by pediatric surgeon is sufficient for the surgical management of conjoined twins. Occasionally, emergency separation is needed; low survival rates are expected in this circumstance because of the poor condition of the twins and the limited availability of imaging exams. A good anatomical survey and proper surgical planning must precede the separation, and the twins must be as healthy as possible. Recent advances in imaging techniques for preoperative investigations provide adequate anatomic diagnosis and predict the possibility of separation. Moreover, advances in anesthetic care and postoperative critical care have improved outcomes and survival rates.

\section{Conclusion:}

A full assessment of shared structures and other associated anomalies should be performed before separation is attempted. The overall success of 
conjoined twin separation depends on the experience and preparedness of treating team led by pediatric surgeon and resources available at the hospital. No single discipline can expect to have all the necessary talents or completely up-to-date information on every conceivable reconstructive technique. Long-term follow-up should be performed.

\section{Acknowledgments}

Department of Pediatric Surgery, Anesthesiology, Plastic Surgery, Neurosurgery, Orthosurgery, Thoracic Surgery, Radiology and Imaging, Gynae and Obstetrics, Urology, Pediatrics, Neonatology, Transfusion Medicine, Clinical Pathology of Dhaka Medical College Hospital and Institute of Nuclear Medicine and Allied Sciences, Dhaka-1000, Bangladesh.

\section{References}

1. Jackson OA, Low DW, Larossa D. Conjoined twin separation: lessons learned. Plast Reconstr Surg. 2012;129(4):956-63.

2. Rode H, Fieggen AG, Brown RA, Cywes S, Davies MR, Hewitson JP, et al. Four decades of conjoined twins at Red Cross Children's Hospital - lessons learned. S Afr Med J. 2006;96(9 Pt 2):931-40.

3. Spencer R. Anatomic description of conjoined twins: a plea for standardized terminology. J Pediatr Surg. 1996;31(7):941-4.

4. Tannuri, Ana Cristina Aoun, Batatinha, Julio Americo Pereira, Velhote, Manoel Carlos Prieto
\& Tannuri, Uenis. Conjoined twins: twenty years' experience at a reference center in Brazil. Clinics 2013;68(3), 371-7.

5. Berezowski AT, Duarte G, Rodrigues R, de Carvalho Cavalli $R$, dos Santos $R$ de $O$, de Andrade Vicente $Y A$, et al. Conjoined twins: an experience of a tertiary hospital in Southeast Brazil. Rev Bras Ginecol Obstet. 2010;32(2):61-5.

6. Spitz L, Kiely EM. Conjoined twins. JAMA. 2003;289(10):1307-10.

7. Filler RM. Conjoined twins and their separation. Semin Perinatol. 1986;10(1):82-91.

8. Spitz L, Kiely EM. Experience in the management of conjoined twins. Br J Surg. 2002;89(9):1188-92.

9. Shi CR, Cai W, Jin HM, Chen F, Zhou Y, Zhou DX. Surgical management to conjoined twin in Shanghai area. Pediatr Surg Int. 2006;22(10):791-5.

10. Saguil E, Almonte J, Baltazar W, Acosta A, Caballes A, Catangui A, et al. Conjoined twins in the Philippines: experience of a single institution. Pediatr Surg Int. 2009;25(9):775-80.

11. Cywes S, Millar AJW, Rode H, Brown RA. Conjoined twins: the Cape Town experience. Pediatr Surg Int. 1997;12(4):234-48.

12. Rabeeah A. Conjoined twins - past, present, and future. J Pediatr Surg. 2006;41(5):1000-4. 